\title{
Insight
}

\section{Developing Adaptive Capacity to Droughts: the Rationality of Locality}

\author{
Lisa W. Welsh ${ }^{1}$, Joanna Endter-Wada ${ }^{1,2,3}$, Rebekah Downard $^{2,3}$ and Karin M. Kettenring ${ }^{2,3}$
}

\begin{abstract}
The Bear River is driven by a highly variable, snow-driven montane ecosystem and flows through a droughtprone arid region of the western United States. It traverses three states, is diverted to store water in an ecologically unique natural lake, Bear Lake, and empties into the Great Salt Lake at the Bear River Migratory Bird Refuge (BRMBR). People in the Bear River Basin have come to anticipate droughts, building a legal, institutional, and engineered infrastructure to adapt to the watershed's hydrologic realities and historical legacies. Their ways of understanding linked vulnerabilities has led to what might appear as paradoxical outcomes: farmers with the most legally secure water rights are the most vulnerable to severe drought; managers at the federal Bear River Migratory Bird Refuge engage in wetland farming and make unlikely political alliances; and, increased agricultural irrigation efficiency in the Bear River Basin actually threatens the water supply of some wetlands. The rationality of locality is the key to understanding how people in the Bear River Basin have increased their adaptive capacity to droughts by recognizing their interdependencies. As the effects of climate change unfold, understanding social-ecological system linkages will be important for guiding future adaptations and enhancing resilience in ways that appropriately integrate localized ecosystem capacity and human needs.
\end{abstract}

Key Words: adaptive capacity; drought; social-ecological systems (SES); vulnerability; water resources management; wetlands

\section{INTRODUCTION}

The Western United States is a drought-prone region that has become even more susceptible to water scarcity with increasing population growth and climate change. Humandriven ecological changes have been occurring at a much faster rate in the late 20th and early 21 st centuries than previously experienced (Berkes et al. 2003, Folke 2006). Berkes and Folke (1998) use the term "social-ecological systems (SESs)" to emphasize the linkages and interactions between social and ecological systems. SESs are complex, adaptive systems that are composed of natural resources, resource users, infrastructure, infrastructure managers, institutional rules, and the external environment (Anderies et al. 2004). The resilience concept has been integrated in SES research to understand how change in SESs can be managed through adaptations and coping mechanisms (Folke 2006). Resilience and adaptive capacity need to be analyzed in terms of linked SESs because only considering the social system may lead to solutions that overestimate ecosystems' capacity to adapt and only focusing on ecosystems may lead to solutions that neglect human values (Folke 2006, Smit and Wandel 2006).

Likewise, the Ways of Knowing framework explains that multiple ways of knowing about social and ecological problems need to be recognized to create policies that encompass the linkages in SESs (Schneider and Ingram 2007). People use many different tools to make sense of relationships between human and nonhuman elements in a policy space. These multiple ways of knowing include scientific, political, and experiential perspectives and are constantly evolving. In addition, combining different types of knowledge is an important dimension of adaptive capacity to generate coping strategies (Armitage 2005). Contextualized analyses show that variations in factors, such as time and geography, can affect people's interdependencies through their use of resources (Schneider and Ingram 2007, Endter-Wada et al. 2009, Ingram and Endter-Wada 2009, Endter-Wada and Blahna 2011). Understanding how and why people are linked to ecosystems can help resource managers create management plans that analyze an ecosystem's ability to sustain human uses (EndterWada and Blahna 2011).

Managing human responses to drought cycles is exacerbated by climate change (Easterling et al. 2000, Huntington 2006, Knapp et al. 2008). A system's adaptive capacity allows the system to cope with hazards that accompany phenomena like climate variability (Brooks and Adger 2004). Adaptive capacity depends on learning from previous experiences with vulnerability to develop strategies to cope with future changes (Brooks and Adger 2004, Armitage 2005). A SES's adaptive capacity relies heavily on the system's contextual socioinstitutional attributes, because those attributes influence how well people in a system can act collectively to shape adaptation. Armitage (2005) calls for more place-based analyses to better understand the "socio-institutional conditions, risks, and interdependencies" that shape adaptive capacity. Adaptive capacity is scale-dependent and adaptation decisions by individuals in a SES are not independent of one another (Adger and Vincent 2005).

In this insight article, we use a case study to interpret how vulnerability, locality, and fairness interact with adaptive capacity. Using key-informant interview data and historical analyses of secondary documents, we present a case study of

${ }^{1}$ Department of Environment and Society, Utah State University, ${ }^{2}$ Ecology Center, Utah State University, ${ }^{3}$ Department of Watershed Sciences, Utah State University 
a SES and analyze how people's linked interdependencies have led to certain unexpected drought adaptations. We conducted content analysis of data obtained from our multimethod approach for themes and reconstruction of adaptation strategies. In the Bear River Basin, a watershed located at the juncture of Utah, Wyoming, and Idaho, people have come to understand that their vulnerabilities to drought are connected (Endter-Wada et al. 2009). Their ways of understanding their linked social-ecological vulnerabilities has led to seemingly paradoxical outcomes that are actually highly localized efforts to respond to drought in ways that seem fair within this particular set of circumstances. These efforts, such as the novel alliances created between wetland managers and farmers, make the Bear River Basin an interesting example of how successful adaptations can stem from community-based learning. We argue that there is a contextualized rationality involved in the way people have organized their relationships with the environment and with each other in this locality to increase their adaptive capacity to changing water availability.

\section{THE BEAR RIVER BASIN AS A SOCIAL- ECOLOGICAL SYSTEM}

The Bear River Basin is a subbasin of the Great Salt Lake Watershed (Fig. 1). The river starts in the high Uinta Mountains of Utah, then crosses state boundaries five times, from Utah to Wyoming to Utah to Wyoming to Idaho to Utah, before ending up in the Great Salt Lake. The river is approximately 500 miles long and is diverted to store water in an ecologically unique natural lake, Bear Lake, and empties into the Great Salt Lake at the Bear River Migratory Bird Refuge (BRMBR; Jibson 1991).

The flora and fauna of the Bear River Basin have adapted to drought either by tolerating it or, in the case of many birds, avoiding it if possible by migrating elsewhere (Haig et al. 1998, Ivey and Herziger 2006, Evans and Martinson 2008). In contrast, people have adapted to this hydro-ecologic reality by capturing and storing high seasonal and interannual river flows for controlled release and use during dry periods (Jibson 1991, Denton 2007). The Bear River is a fully appropriated and a highly manipulated and managed hydrologic system (McCarthy 1987, Jibson 1991). Sustaining wetland ecosystem services and addressing environmental equity while responding to drought and predicted climatic change is shaped by this contextual reality.

Brooks and Adger (2004) explain that a society's adaptive capacity depends on the ability of its people to act collectively and resolve conflicts. Endter-Wada et al. (2009) conducted an in-depth case study that described the unfolding history of how people in the Bear River Basin have learned to cooperate and increase their adaptive capacity in times of drought. They found that conflict and cooperation over water resources constantly evolves, based on people's ways of knowing water and each other. These ways of knowing are often shaped by the geographic and historic context of a place, and are framed by the resolution of past negotiations and settlements (Schneider and Ingram 2007). In the case of the Bear River Basin, people have acknowledged their interdependencies through creation of specific innovations in the law of that river (Endter-Wada et al. 2009).

Fig. 1. The Bear River Basin is divided into three administrative divisions for water management. (Map created by Adrian Welsh).

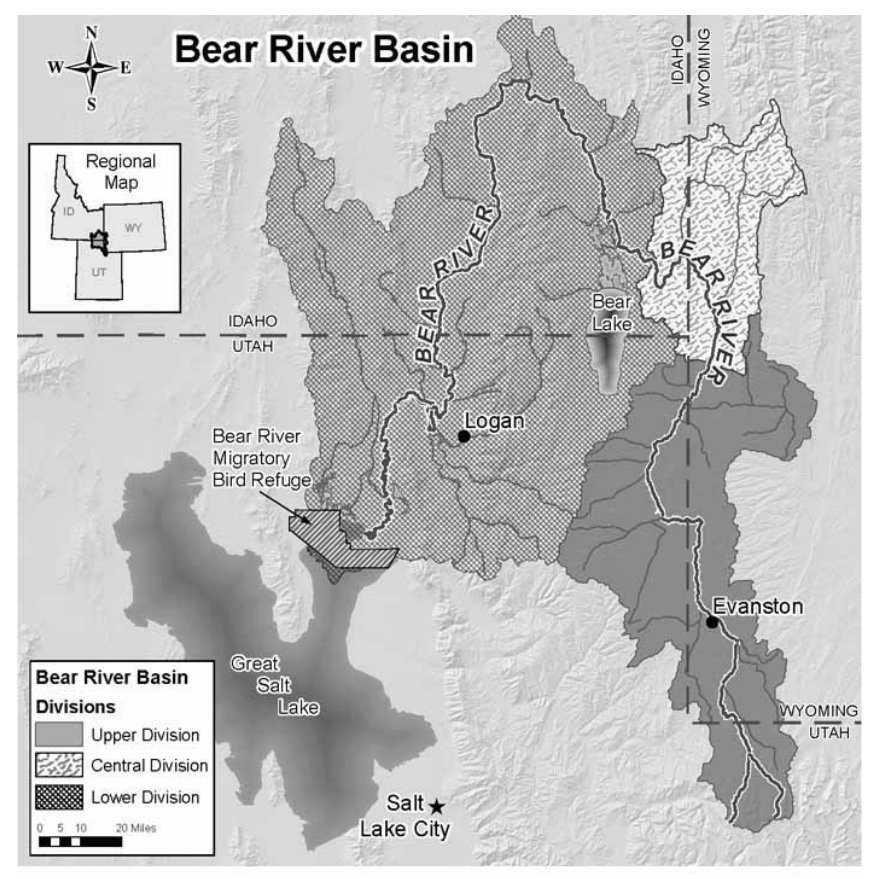

The right to water in the West is allocated on a first-come, first-served basis under prior appropriation water law. Because the Bear River flows through three states and serves multiple uses and users, additional compacts and settlement agreements were crafted to foster cooperation in the use of water. The Bear River Compact establishes water rights and obligations of Idaho, Utah, and Wyoming and divides the Bear River Basin into three main administrative divisions: Upper Division, Central Division, and Lower Division (Fig. 1). Everyday operation of the Bear River is left to the three states unless there is a water emergency to trigger interstate regulation and invoke the involvement of the interstate Bear River Commission (Jibson 1991, Boyce 1996, Endter-Wada et al. 2009).

Further complicating water allocation in the Bear River Basin, large senior water rights were secured by early settlers who established farms near the end of the river, in the Lower 
Fig. 2. Bear Lake hydrograph, 1910-2012. The dashed line shows the level of Bear Lake when storage rights of the Upper and Central Divisions are restricted.

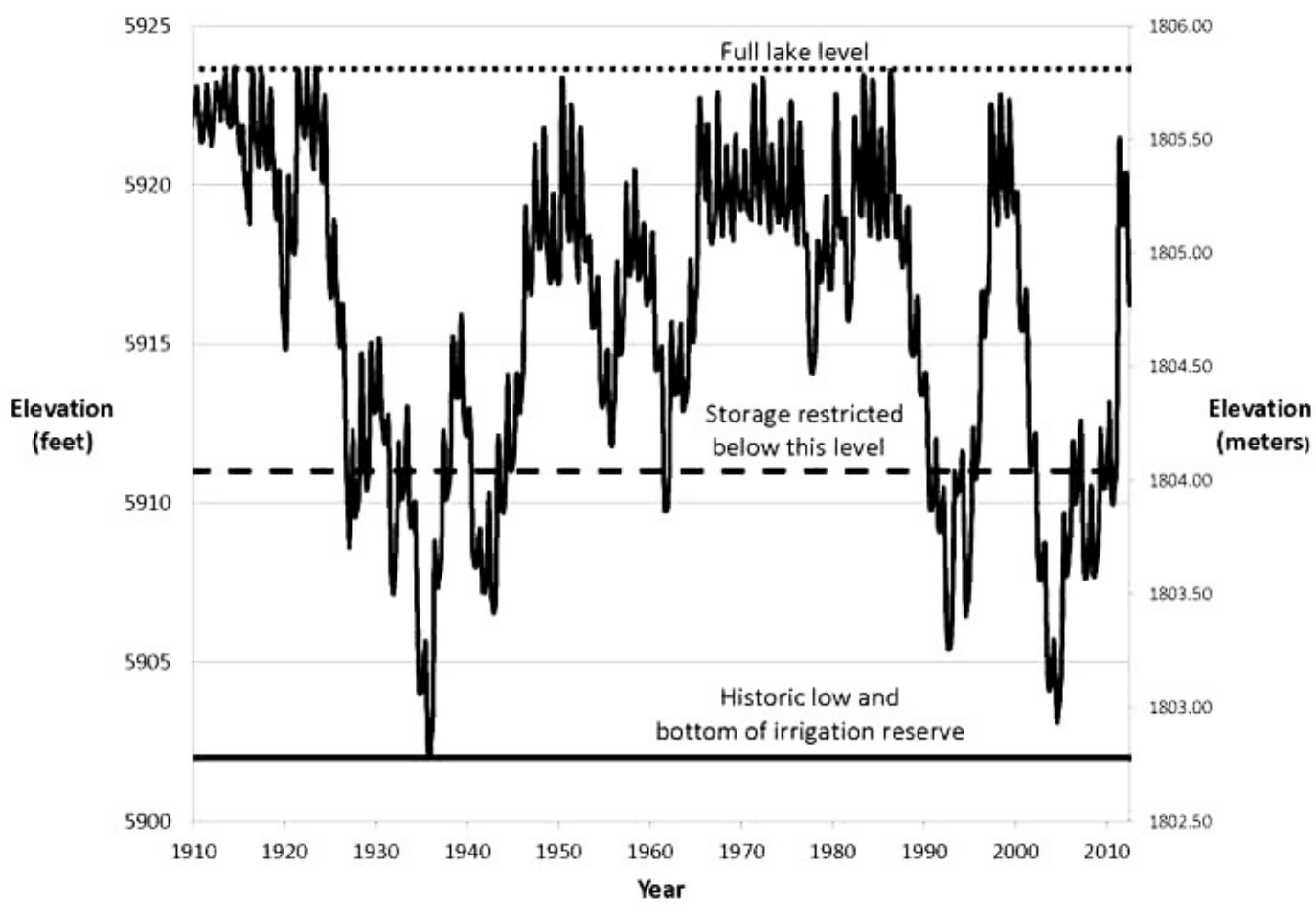

Division. Bear Lake, in the middle of the river system, has been engineered so that the top 21.65 feet (specified as such in the Bear River Compact), from 5902 feet in elevation to 5923.65 feet in elevation, serves as an irrigation reserve for irrigators in the Lower Division (Fig. 2; McCarthy 1987, Jibson 1991). The average allocation from this irrigation reserve is 230,000 acre-feet of water. The Bear River Basin is unique in that the majority of water rights below Bear Lake are held by a private hydropower company, PacifiCorp, which is responsible for delivering storage water to irrigators to supplement their natural flow rights (McCarthy 1987, Jibson 1991). PacifiCorp and irrigators voluntarily abide by the Bear Lake Settlement Agreement, negotiated between affected parties during a drought in the early 1990s. This agreement mitigates the risk of Bear Lake levels dropping below 5904 feet in elevation to prevent Bear Lake reaching its historical low of 5902 feet, the bottom of the irrigation reserve (EndterWada et al. 2009).

Although the Bear River has mostly been manipulated to serve agricultural interests, the system is also engineered to serve important ecological functions and services. The Bear River Migratory Bird Refuge is located at the Bear River's delta where it enters the Great Salt Lake. The BRMBR is part of the U.S. National Wildlife Refuge System managed by the U.S. Fish and Wildlife Service (USFWS). These desert wetlands are not only a critical part of the Great Salt Lake ecosystem, but are internationally significant for migratory birds on the Central and Pacific Flyways. The BRMBR's $290 \mathrm{~km}^{2}$ of wetlands, playas, and mudflats are used by more than 260 species of birds (Olson et al. 2004, Denton 2007, Evans and Martinson 2008). Management of the BRMBR is largely driven by seasonal water availability, which is influenced not only by climatic and hydrologic realities but by the way the BRMBR relates to other stakeholders, particularly irrigators, many with more senior and more secure water rights.

\section{DROUGHT VULNERABILITIES IN THE BEAR RIVER BASIN}

Drought vulnerabilities are shaped not only by natural contexts, but social contexts as well (Adger 2006, Smit and Wandel 2006, O'Brien et al. 2007). Human vulnerability to drought can also be contextually shaped by political, institutional, geographic, economic, and social structures (O'Brien et al. 2007). Drought vulnerabilities are linked to how SESs function (Endter-Wada et al. 2009). Adler (2010) describes ways in which law and institutions can actually increase vulnerability to droughts through policies that are reactive rather than proactive in mitigating or adapting to drought impacts. Additionally, people's individual vulnerabilities within the system vary with their position in social and political 
geography (Ingram and Endter-Wada 2009). For instance, the prior appropriation doctrine guarantees that senior water right holders receive their full allocations, even when some junior water right holders may not get any water at all during times of shortage. Thus, senior water right holders have little incentive to increase their adaptive capacity to drought until a very severe drought threatens their own water supplies (Adler 2010). The linked vulnerabilities of natural and social contexts are particularly evident in the Bear River Basin. To increase the adaptive capacity of the whole system, individual actions must be understood within a contextualized reality whereby people come to know and to care about all uses in the SES in relation to each other.

Bear Lake water levels (Fig. 2) are often used as an indicator of drought in the Bear River Basin. When the water elevation level of Bear Lake drops below 5911 feet, storage rights above Bear Lake in the Central and Upper Divisions are restricted so that Bear Lake can receive as much natural flow water as possible. The Bear Lake hydrograph (Fig. 2) reveals that drought conditions when the Central and Upper Divisions experience storage restrictions are frequent occurrences. This juxtaposition illustrates that people and other ecological elements in the Bear River Basin are vulnerable not only to natural climatic and hydrologic variation but also to water use by neighboring entities as structured by the Basin's governing water law.

Human adaptation to drought in the Bear River Basin has created its own set of ecological and social vulnerabilities. The system is already drought-prone and western water law pressures water managers to fully allocate and utilize Bear River water. This leaves less flexibility to cope with more severe droughts being predicted with climate change for the Intermountain West (Wagner 2009, Jin et al. 2011, Gillies et al. 2012). Current water policies in the Bear River Basin would appear to leave irrigators in the Upper and Central Divisions more vulnerable to drought than those in the Lower Division, because their access to water is legally restricted.

Likewise, the Bear River Migratory Bird Refuge is vulnerable to both upstream and more local senior water right holders. Within the Lower Division, the BRMBR, which lies downstream of the most senior agricultural users on the river, remains vulnerable to changes in water availability that may divert water away from agricultural uses. Because the BRMBR's water rights to the Bear River (with the primary right dated 1928) are junior to nearby water users whose rights date back to the 1890 s, the BRMBR is nearly completely dependent on agricultural return flows during the irrigation season (Downard 2010). This leaves them vulnerable to forces that change the volume and timing of agricultural return flows, including climate change, urban development, and increased irrigation efficiency.
In addition, the Bear River Basin as a whole remains vulnerable to the water needs of large, growing municipalities outside the watershed located along the Wasatch Front in the greater Ogden-Salt Lake City-Provo metropolitan corridor (Utah Division of Water Resources 2000, 2004). In 1991, the Utah State Legislature passed the Bear River Development Act (Utah Code 73-26-101 to 73-26-507). This Act followed several years of study regarding the estimated 1.2 million acrefeet of water that annually flows into the Great Salt Lake from the Bear River. The Development Act allows Utah's Division of Water Resources to connect the Bear River with a pipeline so that water can be delivered to the Wasatch Front within the next 20 years (Utah Division of Water Resources 2000, 2004). This Act further illustrates how western water law can increase drought vulnerability by encouraging rivers to be fully developed and reducing human flexibility to use water supplies in sync with hydrologic cycles.

These hydrological, ecological, and social vulnerabilities are linked, and every action on the river affects the health of the whole system. Bob Barrett, Project Leader and Manager of the Bear River Migratory Bird Refuge, explained that although the BRMBR is often considered the last downstream user of the Bear River, the Bear River flows into the Great Salt Lake, an important ecosystem for bird life and the highly productive brine shrimp industries. Barrett considers one of his responsibilities is ensuring that a sufficient quantity and acceptable quality of water passes through the BRMBR to help support the Great Salt Lake ecosystem. Even though all water users may not feel the same sense of responsibility to their neighboring water users, Barrett's perspective emphasizes how water users are invariably linked in a SES.

\section{DEVELOPING ADAPTIVE CAPACITY THROUGH UNDERSTANDING SOCIAL-ECOLOGICAL INTERDEPENDENCIES}

The novel ways in which water users in the Bear River Basin have responded to drought vulnerability emphasize the limitations of western water law to fully account for societal changes that have occurred since the law was implemented. Some observers argue that the prior appropriation doctrine is outdated and was created in an era much different than the one that characterizes the U.S. West today (Wilkinson 1992, Bates et al. 1993). Western water policy has been driven by the idea that water, once appropriated, is a permanent consumptive right, but water rights established under prior appropriation have not always been equitable and public values of water not always considered (Bates et al. 1993). The prior appropriation doctrine does not necessarily consider water as part of a linked, functioning SES, because water rights are not connected to the land and are transferable between users (Bates et al. 1993, Getches 2009). However, water users in the Bear River Basin recognize that their water uses are interdependent and have modified their practices in paradoxical and novel ways to adapt 
to a water law inadequate to address the growing and multiple demands for its use. Locality helps explain how people in the Bear River Basin have increased their adaptive capacity to respond to drought in ways that seem fair.

People's ways of understanding and adapting to linked SES vulnerabilities in the Bear River has led to three seemingly paradoxical outcomes: (1) farmers with the most legally secure water rights and greatest access to storage water are the most vulnerable to severe drought; (2) managers at the federal Bear River Migratory Bird Refuge engage in wetland farming, make political alliances with other irrigators and a power company, and support construction of a dam; and (3) increased agricultural irrigation efficiency actually threatens the water supply of some wetlands. These paradoxical outcomes are evidence of Bear River Basin water users' abilities to change perceptions and foster innovative, novel solutions in their particular complex SES, which is an important aspect of adaptive capacity (Walker et al. 2002, Armitage 2005).

\section{Conundrums in reducing agricultural vulnerability to drought}

Irrigators in the Upper and Central Divisions have been able to persist through even the most difficult droughts more easily than irrigators in the Lower Division. In 2004, Bear Lake levels were the lowest they had been since 1935, marking a significant drought. Senior water right holders in the Lower Division were impacted severely by the 2004 drought, as explained by Bear River Basin water managers. One interviewee noted that irrigators in the Lower Division had a "false sense of security" because they have access to storage water in Bear Lake and are accustomed to a more stable water supply. As senior water right holders, irrigators in the Lower Division rarely had their full water allocation reduced. In 2004, Bear Lake storage water ran out for the first time since the 1930s drought, and shareholders of the oldest water rights took out crop insurance, which they had never done previously. Conversely, irrigators in the Upper and Central Divisions entered the 2004 drought with a "business as usual" approach. As junior water right holders, irrigators in those two divisions do not expect to regularly receive their full water allocations. Their greater experience with drought has people in the Upper and Central Divisions continually anticipating that they will be living on the margins. As one water manager explained, "they know what's coming their way and live with it." This adaptation supports Gallopín's concept (2006) that vulnerability may not necessarily be negative. He discusses the possibility of a "positive vulnerability" that leads to increased resilience, because a history of past exposures to perturbations, such as drought, can be important to build resilience to system changes (Gallopín 2006). Stated simply, the Upper and Central Divisions' exposure to drought vulnerability has lead irrigators to increase their adaptive capacity in ways that Lower Division irrigators have not.
The Upper and Central Divisions are located at higher elevations than the Lower Division. Along with scarce water supplies, these higher elevations are characterized by greater frost risk and dry soils with low concentrations of organic matter (Boettinger 2009). To adapt to these adverse conditions, irrigators in the Upper and Central Divisions can only grow a few varieties of crops, primarily meadow hay that requires only one to two water applications per season to provide winter feed for cattle. In contrast, irrigators in the Lower Division are located closer to markets and urban centers and have large investments in farm equipment to grow a wider variety of higher valued cash crops. Proximity to Salt Lake City led to irrigators settling in the Lower Division first, where they were able to obtain senior water rights in the Bear River Basin under the prior appropriation doctrine. As senior water right holders, irrigators in the Lower Division feel more secure in their water supply and operate agricultural systems that are dependent on a constant supply of water. Irrigators in the Lower Division receive higher financial returns during average water years so that they can ideally absorb the greater impacts they experience during severe drought. However, this system in the Lower Division is not sustainable over multiple years of severe water shortages. Irrigators in the Upper and Central Divisions generally buy more hay or sell cattle if drought damages their crops. In other words, the Upper and Central Divisions have increased their adaptive capacity, because the legal institutions forced the irrigators to maintain agricultural systems that are structured to sustain varying levels of perturbations from droughts (Walker et al. 2002, Folke 2006, Gallopín 2006). As junior water right holders, irrigators in the Upper and Central Divisions are knowingly more vulnerable to drought and respond accordingly.

\section{Enigma of wetland farming at the USFWS Bear River Migratory Bird Refuge}

Like the Upper and Central Divisions, the locations of wetlands in the Bear River Basin have influenced how wetland managers have chosen to adapt to scarce water supplies. The Bear River Migratory Bird Refuge occupies an important position in the landscape that is critical and problematic. Ecologically, it is at the nexus between two different environments, the Bear River and the Great Salt Lake. Geopolitically, it occupies an important nexus between public and private lands, and between rural and urban counties. Legally, its water rights are at the nexus of senior and junior as well as municipal and agricultural water rights. These nexuses highlight that different types of locality, not just geographic location, must be considered when analyzing the linkages between elements in a SES. The legal infrastructure considers the water and land for wetlands as separate resources that are not connected, whereas SES perspectives would see them as linked parts of a larger system (MacDonnell 1991). BRMBR managers understand that their water rights are junior to other users and they have worked with senior water right 
Fig. 3. The Bear River Migratory Bird Refuge. The refuge is divided into ten wetland units. (Map created by Adrian Welsh).

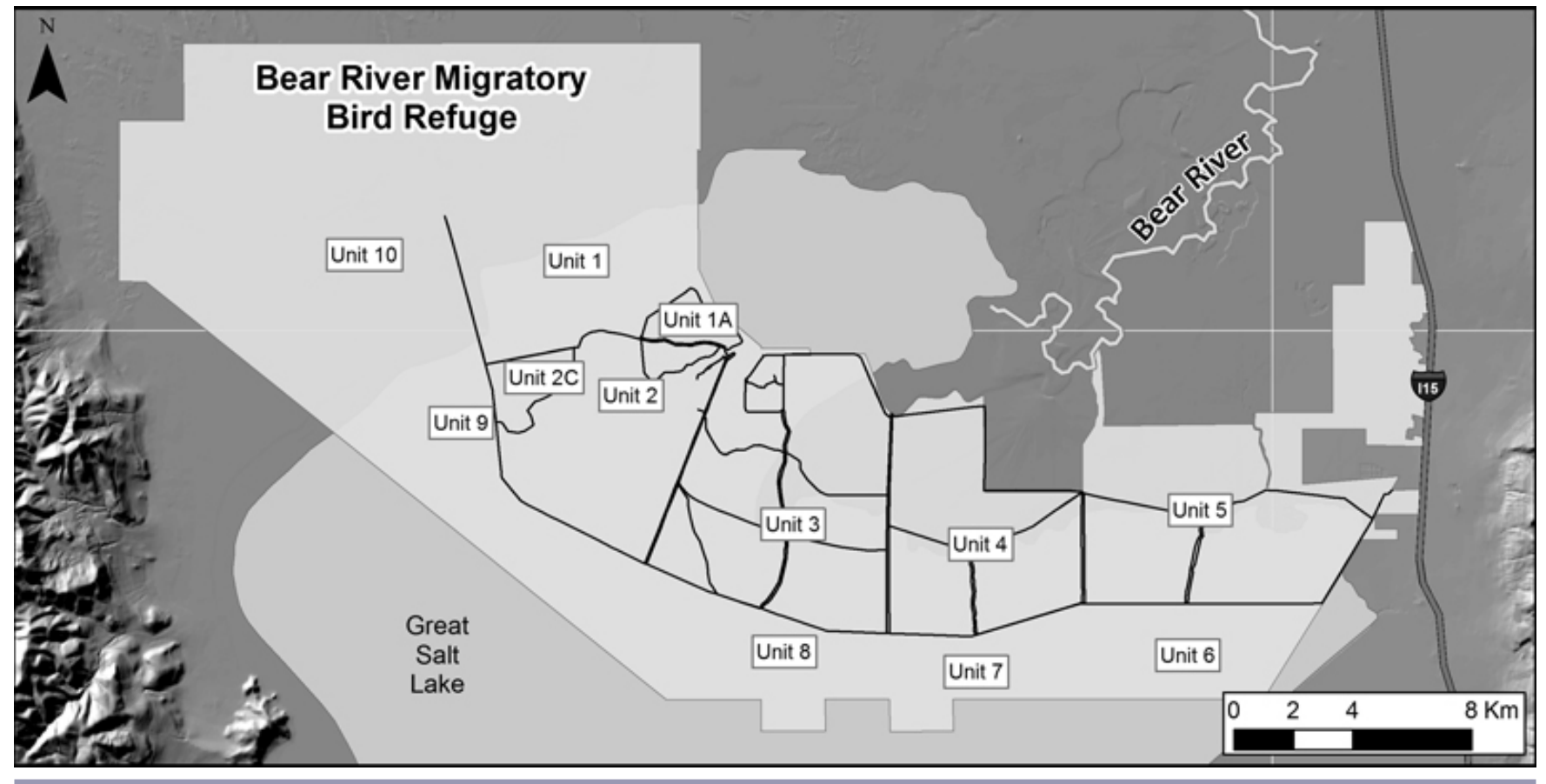

holders to obtain as much water as is possible legally and practically.

BRMBR managers have worked within the prior appropriation doctrine by acquiring water rights to irrigate their wetlands through a system of canals and dikes, making BRMBR managers essentially wetland farmers. Upon the BRMBR's establishment in 1928, BRMBR managers had to secure and utilize water rights and began constructing water control structures and subdividing the wetland complex into units (Fig. 3). Every year, managers estimate summer supply based on the winter's snowpack and then prioritize which wetland units they think can be kept wet based on projected water availability and other management needs, e.g., invasive species, dike repair. As water becomes scarce toward the end of the irrigation season, they let some units go dry and actively manage water levels in others.

Although there is nothing natural about this water management, BRMBR managers are actively reducing the BRMBR's vulnerability to drought by modifying the sensitivity of the system to drought perturbations in this SES (Gallopín 2006). Because wildlife propagation is the purpose that justifies the BRMBR's water use, managers aim to maximize the amount and types of migratory bird habitat available. By purposively controlling application of water to various units in the BRMBR, managers can reduce birds' drought exposure through habitat manipulation, an important factor in reducing vulnerability to drought (Adger 2006,
Gallopín 2006). This system of water management, although unusual, is effective enough that it has been adopted in other refuges along the river. Refuges upstream of the Bear River Migratory Bird Refuge also seek to exercise maximum control over water within their particular sets of SES constraints to create the best possible wetland habitat. Ironically, these other wildlife refuges, most with smaller, or no legal water rights at all, generally have a more secure water supply because of their advantageous geographic position in relation to agricultural and hydropower water uses (Downard 2010).

BRMBR managers have also built seemingly unlikely alliances with irrigators and PacifiCorp, the company that operates Bear Lake and other upstream reservoirs for hydropower and irrigation purposes. Recent history suggests that these interests are at odds with one another: the destruction of wetlands for agricultural land development was once encouraged by the United States government (Vileisis 1997, Mitsch and Gosselink 2000, Langston 2003). However, contextualized history plays out differently in the SES of the Bear River Basin: BRMBR managers recognize that their late summer water supply is dependent on either deliveries of agricultural storage water or return flows from agricultural flood irrigation, and each of these water sources is dependent upon connections between irrigators and PacifiCorp. Consequently, BRMBR managers have built relationships with these other water users to help ensure that they can exercise flexibility in their own water use. The majority of 
these irrigators have been supportive of the BRMBR's quest for water. Many people in the rural Bear River Basin have long traditions of hunting and understand that it is necessary and equitable for the BRMBR to also have water to maintain wildlife habitat (Downard 2010).

Furthermore, interviewees from the USFWS described how the Service has joined irrigators in supporting a dam in the lower reaches of the Bear River. A reservoir would give the BRMBR its own storage water to maintain stable water levels in its wetlands throughout the summer (Denton 2007). Depending on where the storage reservoir is built and how water releases are delivered to users, BRMBR managers see a potential opportunity to enhance corridors of riparian wetland habitat that would link USFWS refuges with larger wetland complexes. These unlikely alliances suggest that wildlife agencies face the same threats to their water supply as other water users. Smit and Wandel (2006) explain that adaptive capacity is shaped and constrained by social, political, and economic processes. The presence of other water users in the Bear River Basin affect the BRMBR's vulnerabilities to scarce water supplies, but BRMBR managers have learned that alliances with these other water users have also helped increase the BRMBR's adaptive capacity to drought.

\section{Unexpected impacts of agricultural irrigation efficiency on wetlands}

As another example of SES vulnerabilities and paradoxical alliances, interviewees from the USFWS explained that the Service opposes the transfer of water from what often is perceived to be more consumptive agricultural uses to less consumptive uses like municipal and industrial (M\&I) uses. Western water law considers water that reaches the Great Salt Lake as wasted if it cannot be harnessed and used, as illustrated by the Bear River Development Act. If water currently used on upstream agricultural land is transferred to M\&I uses, irrigation runoff will likely cease to flow through the BRMBR into the Great Salt Lake. Understanding the mutual dependencies and interactions of neighbors in SESs, particularly in regard to water flow pathways, is an important element of how social learning relates to developing higher adaptive capacity (Pahl-Wostl 2002).

BRMBR managers are all too aware of the increased vulnerability that this efficiency paradox creates, in which increased irrigation efficiency leads to less water for wetlands. Responding to this vulnerability further emphasizes the importance of understanding one's place in both geographic and social contexts. The BRMBR's location at the end of the Bear River allows it to receive flows from agricultural runoff, but the legal context of prior appropriation endangers that source of water. Because of western water law, water that is saved is either stored for later use or becomes available for the next-in-line legal priorities. As Bear River irrigators become more efficient, they have been able to conserve more Bear Lake storage water and manage it better on an interannual basis to meet deliveries to irrigators whose rights have more seniority than most rights held by the BRMBR. This paradox raises the interesting lesson that we cannot assume that efficiency is good without carefully juxtaposing it with equity concerns. To increase their adaptive capacity, wetland managers need to understand that increased irrigation efficiency may not always benefit downstream wetlands, because the political context limits what happens to the saved water. This situation emphasizes the importance of wetland managers to act as political players and take part in the broader societal institutions of the SES to successfully manage natural resources.

\section{CONCLUSIONS}

This case study of the Bear River Basin illustrates that particularities of the law of the Bear River have helped structure water users' adaptations to drought. Institutions, such as water law, provide links that connect social and ecological systems in a SES (Folke et al. 1998, Herrfahrdt-Pähle and Pahl-Wostl 2012). Water law shapes not only the relationships between people and water but also people's relationships with each other (Endter-Wada et al. 2009). The challenge is that SESs are marked by change, and remaining resilient throughout disturbances requires adaptive processes supported by social learning (Berkes et al. 2003, HerrfahrdtPähle and Pahl-Wostl 2012). Inflexible institutions can constrain adaptive capacity and increase the vulnerability of a system (Adger and Vincent 2005).

People in the Bear River Basin have adapted not only to drought but also to the constraints of western water law so that they can have the needed flexibility to react to water uncertainties in a changing environment. Some of these adaptations have been in the form of informal rules and agreements with other water users (Endter-Wada et al. 2009). Ostrom (1992) explains that these informal institutions can be very effective in governing common-pool resources, such as water, when they are designed to work within the local context. Pahl-Wostl (2009) emphasizes that a balance between formal and informal institutions is necessary for context specific social learning to lead to flexible regulations that allow for a higher adaptive capacity. People must recognize their location within the social system as well as the ecological system to find a balance between continuity and change that will allow access to water to sustain the system over evolving circumstances.

There is a contextualized rationality involved in the way people have organized their relationships with the environment and with each other in the Bear River Basin. However, this "rationality" is one framed by human logic, not necessarily ecological logic. The nature of ecological and human vulnerabilities changes over time and within particular 
contexts. As people in the Bear River Basin have experienced drought vulnerabilities, they have collaborated and learned from each other in their place-specific relationships to increase not only their individual adaptive capacity, but the adaptive capacity of the SES as a whole. In turn, developing a higher adaptive capacity has lowered the SES's vulnerability to drought.

However, the rationality of adaptation in the Bear River Basin has been built on a preclimate change reality. Climate change introduces new uncertainties and reveals how, in pursuing adaptive strategies that attempt to exercise greater control over scarce water supplies, people there have become ever more vulnerable to the limitations of human knowledge. The way people have adapted to the arid and drought-prone hydrology of the Bear River Basin places great onus on their ability to discern which uses, which wetlands, which lakes, and which birds need water, at what times, and at what consequences over the long term. Pursuing environmental equity has encouraged people to adapt existing water laws to societal and climatic changes and, perhaps more importantly, has linked people in the Bear River Basin in new and unexpected ways. Creating water policies built on understanding socialecological system linkages can guide future adaptations and enhance resilience in ways that appropriately integrate localized ecosystem capacity and human needs.

Responses to this article can be read online at: http://www.ecologyandsociety.org/issues/responses. $\mathrm{php} / 5484$

\section{Acknowledgments:}

This work was supported by: the USDA-CREES Drought Management, Utah project, awards 2008-34552-19042 and 2009-34552-19746; Utah Agricultural Experiment Station Projects UTAO1120 and UTAO1077; and NSF grant 1038973. An earlier version of this paper was given as an invited case study presentation at the Ecological Society of America's (ESA) First Emerging Issues in Ecology Conference, "Water Ecosystem Services, Drought, and Environmental Justice" in Athens, GA, on November 9-12, 2009. The two-part multimedia presentation can be accessed as Case Study 9 from this ESA website: http://www.esa.org/millenniumconf/2009/ case_studies.php. The authors wish to thank people in the Bear River Basin who were interviewed and provided information. They extend appreciation to the ESA and the USU Ecology Center for travel support to participate in the conference.

\section{LITERATURE CITED}

Adger, W. N. 2006. Vulnerability. Global Environmental Change 16:268-281.
Adger, W. N., and K. Vincent. 2005. Uncertainty in adaptive capacity. Comptes Rendus Geoscience 337:399-410. http://dx. doi.org/10.1016/j.crte.2004.11.004

Adler, R. W. 2010. Climate change and the hegemony of state water law. Stanford Environmental Law Journal 29:1-61.

Anderies, J. M., M. A. Janssen, and E. Ostrom. 2004. A framework to analyze the robustness of social-ecological systems from an institutional perspective. Ecology and Society 9(1): 18. [online] URL: http://www.ecologyandsociety.org/ vol9/iss 1/art18/

Armitage, D. 2005. Adaptive capacity and community-based natural resource management. Environmental Management 35 (6):703-715. http://dx.doi.org/10.1007/s00267-004-0076-z

Bates, S. F., D. H. Getches, L. J. MacDonnell, and C. F. Wilkinson. 1993. Searching out the headwaters: change and rediscovery in western water policy. Island Press, Washington, D.C., USA.

Berkes, F., J. Colding, and C. Folke. 2003. Introduction. Pages 1-29 in F. Berkes, J. Colding, and C. Folke, editors. Navigating social-ecological systems: building resilience for complexity and change. Cambridge University Press, Cambridge, UK.

Berkes, F., and C. Folke, editors. 1998. Linking social and ecological systems: management practices and social mechanisms for building resilience. Cambridge University Press, New York, New York, USA.

Boettinger, J. L. 2009. Soils of Utah. Pages 46-48 in R. E. Banner, B. D. Baldwin, and E. I. Leydsman McGinty, project coordinators. Rangeland resources of Utah. Utah State University Cooperative Extension, Logan, Utah, USA. [online] URL: http://extension.usu.edu/utahrangelands/files/ uploads/RRU_Final.pdf

Boyce, J. 1996. Wrestling with the Bear: a compact approach to water allocation. BYU Journal of Public Law 10 (2):301-324.

Brooks, N., and W. N. Adger. 2004. Assessing and enhancing adaptive capacity. Pages 165-181 in B. Lim and E. SpangerSiegfried, editors. Adaptation policy frameworks for climate change: developing strategies, policies and measures. UNDPGEF Cambridge University Press, Cambridge, UK.

Denton, C. 2007. Bear River: last chance to change course. Utah State University Press, Logan, Utah, USA.

Downard, R. 2010. Keeping wetlands wet: the human hydrology of wetlands in the Bear River Basin. Thesis. Utah State University, Logan, Utah, USA. [online] URL: http:// digitalcommons. usu.edu/cgi/viewcontent.cgi?article $=1825 \&$ context $=$ $\underline{\text { etd }}$

Easterling, D. R., G. A. Meehl, C. Parmesan, S. A. Changnon, T. R. Karl, and L. O. Mearns. 2000. Climate extremes: 
observations, modeling, and impacts. Science 289:2068-2074. http://dx.doi.org/10.1126/science.289.5487.2068

Endter-Wada, J., and D. J. Blahna. 2011. Linkages to public land framework: toward embedding humans in ecosystem analyses by using "inside-out social assessment." Ecological Applications 21(8):3254-3271. http://dx.doi.org/10.1890/10-2392.1

Endter-Wada, J., T. Selfa, and L. W. Welsh. 2009. Hydrologic interdependencies and human cooperation: the process of adapting to droughts. Weather, Climate, and Society 1:54-70. http://dx.doi.org/10.1175/2009WCAS1009.1

Evans, K., and W. Martinson. 2008. Utah's featured birds and viewing sites: a conservation platform for IBAs and BHCAs. Sun Litho, Salt Lake City, Utah, USA.

Folke, C. 2006. Resilience: the emergence of a perspective for social-ecological systems analyses. Global Environmental Change 16(3):253-267. http://dx.doi.org/10.1016/j.

gloenvcha.2006.04.002

Folke, C., F. Berkes, and J. Colding. 1998. Ecological practices and social mechanisms for building resilience and sustainability. Pages 414-436 in F. Berkes and C. Folke, editors. Linking social and ecological systems: management practices and social mechanisms for building resilience. Cambridge University Press, Cambridge, UK.

Gallopín, G. C. 2006. Linkages between vulnerability, resilience, and adaptive capacity. Global Environmental Change 16(3):293-303. http://dx.doi.org/10.1016/j.

gloenvcha.2006.02.004

Getches, D. H. 2009. Water law in a nutshell. Fourth edition. Thomson West, St. Paul, Minnesota, USA.

Gillies, R. R., S. Wang, M. R. Booth. 2012. Observational and synoptic analyses of the winter precipitation regime change over Utah. Journal of Climate 25:4679-4698. http://dx.doi. org/10.1175/JCLI-D-11-00084.1

Haig, S. M., D. W. Mehlman, and L. W. Oring. 1998. Avian movements and wetland connectivity in landscape conservation. Conservation Biology 12(4):749-758.

Herrfahrdt-Pähle, E., and C. Pahl-Wostl. 2012. Continuity and change in social-ecological systems: the role of institutional resilience. Ecology and Society 17(2): 8. http://dx.doi. org/10.5751/ES-04565-170208

Huntington, T. G. 2006. Evidence for intensification of the global water cycle: review and synthesis. Journal of Hydrology 319:83-95. http://dx.doi.org/10.1016/j.jhydrol.2005.07.003

Ingram, H., and J. Endter-Wada. 2009. Frames and ways of knowing: key considerations for policy responses to climate risk and vulnerability. In Proceedings of the Seventh
International Science Conference on the Human Dimensions of Global Environmental Change. International Human Dimensions Programme. 26-30 April 2009, Bonn, Germany.

Ivey, G. L., and C. P. Herziger. 2006. Intermountain west waterbird conservation plan, version 1.2. Waterbird Conservation for the Americas Institute, U.S. Fish and Wildlife Service, Pacific Region, Portland, Oregon, USA.

Jibson, W. N. 1991. History of the Bear River Compact. Bear River Commission, Bountiful, Utah, USA. [online] URL: http://waterrights.utah.gov/techinfo/bearrivc/history.html

Jin, J., S. Y. Wang, and R. R. Gillies. 2011. An improved dynamical downscaling of climate projections for the western United States. Pages 23-38 in J. Blanco and H. Kheradmand, editors. Climate change - research and technology for adaptation and mitigation. InTech Open Access Publisher, New York, New York, USA. http://dx.doi.org/10.5772/22991

Knapp, A. K., C. Beier, D. D. Briske, A. T. Classen, Y. Luo, M. Reichstein, M. D. Smith, S. D. Smith, J. E. Bell, and P. A. Fay. 2008. Consequences of more extreme precipitation regimes for terrestrial ecosystems. BioScience 58:811-821. http://dx.doi.org/10.1641/B580908

Langston, N. 2003. Where land and water meet: a western landscape transformed. University of Washington Press, Seattle, Washington, USA.

MacDonnell, L. J. 1991. Water rights for wetlands protection. Rivers 2(4):277-284.

McCarthy, M. R. 1987. The last chance canal company. Charles Redd Center for Western Studies, Brigham Young University, Provo, Utah, USA.

Mitsch, W. J., and J. G. Gosselink. 2000. Wetlands. Third edition. John Wiley \& Sons, New York, New York, USA.

O'Brien, K., S. Eriksen, L. P. Nygaard, and A. Schjolden. 2007. Why different interpretations of vulnerability matter in climate change discourses. Climate Policy 7:73-88. http://dx. doi.org/10.3763/cpol.2007.0706

Olson, B. E., K. Lindsey, V. Hirschboeck. 2004. Bear River Migratory Bird Refuge habitat management plan. U.S. Fish and Wildlife Service, Brigham City, Utah, USA.

Ostrom, E. 1992. Crafting Institutions for self-governing irrigation systems. ICS Press, San Francisco, California, USA.

Pahl-Wostl, C. 2002. Towards sustainability in the water sector - the importance of human actors and processes of social learning. Aquatic Sciences 64:394-411. http://dx.doi. org/10.1007/PL00012594 
Pahl-Wostl, C. 2009. A conceptual framework for analysing adaptive capacity and multi-level learning processes in resource governance regimes. Global Environmental Change 19:354-365. http://dx.doi.org/10.1016/j.gloenvcha.2009.06.001

Schneider, A. L., and H. Ingram. 2007. Ways of knowing: implications for public policy. In Proceedings of the 2007 Annual Meeting of the American Political Science Association. American Political Science Association. 29 Aug - 2 Sept 2007, Chicago, Illinois, USA. [online] URL: http:// www.cspo.org/documents/ways_of_knowing.pdf

Smit, B., and J. Wandel. 2006. Adaptation, adaptive capacity and vulnerability. Global Environmental Change 16 (3):282-292. http://dx.doi.org/10.1016/j.gloenvcha.2006.03.008

Utah Division of Water Resources. 2000. Bear River development. Utah Division of Water Resources, Salt Lake City, Utah, USA. [online] URL: http://www.water.utah.gov/ brochures/brdev.pdf

Utah Division of Water Resources. 2004. Bear River Basin: planning for the future. Utah Division of Water Resources, Salt Lake City, Utah, USA. [online] URL: http://www.water. utah.gov/planning/SWP/bear/bearRiver-1A.pdf

Vileisis, A. 1997. Discovering the unknown landscape: a history of America's wetlands. Island Press, Washington, D. C., USA.

Wagner, F. H. 2009. Climate change projected for the twentyfirst century and measured for the twentieth in the Rocky Mountain/Great Basin Region. Pages 3-18 in F. H. Wagner, editor. Climate warming in western North America: evidence and environmental effects. University of Utah Press, Salt Lake City, Utah, USA.

Walker, B., S. Carpenter, J. Anderies, N. Abel, G. Cumming, M. Janssen, L. Lebel, J. Norberg, G. D. Peterson, and R. Pritchard. 2002. Resilience management in social-ecological systems: a working hypothesis for a participatory approach. Conservation Ecology 6(1): 14. [online] URL: http://www. consecol.org/vol6/iss1/art14

Wilkinson, C. F. 1992. Crossing the next meridian: land, water, and the future of the west. Island Press, Washington, D. C., USA. 